\title{
THE PATTERNS AND CHARACTERISTICS OF PERI-URBAN SETTLEMENT IN EAST UNGARAN DISTRICT, SEMARANG REGENCY
}

\author{
F.S. Arta ${ }^{\text {a }}$ B.Pigawati ${ }^{\text {a }}$ \\ a Diponegoro University, Indonesia
}

\section{Article Info:}

Received: 27 July 2015

in revised form: 10 September 2015

Accepted: 5 October 2015

Available Online: 31 October 2015

\section{Keywords:}

Settlements characteristic, periurban, East Ungaran District

\section{Corresponding Author:}

Febrina Sri Arta

Universitas Diponegoro,

Semarang, Indonesia

Email: febrina.sri15@pwk.undip.ac.id

\section{Info Artikel:}

Diterima: 27 July 2015

Hasil Revisi: 10 September 2015

Disetujui: 5 Oktober 2015

Publikasi On-Line: 31 Oktober 2015

\section{Kata Kunci:}

Karakteristik Permukiman,

Peri-Urban, Kecamatan Ungaran Timur

\section{Kontak Penulis:}

Universitas Diponegoro,

Semarang, Indonesia

Email:

febrina.sri15@pwk.undip.ac.id
Febrina Sri Arta

Abstract: East Ungaran District is a peri-urban area arising from the urban-rural interaction between Semarang City and Semarang Regency. Interaction of these two regions is supported with the accessibility that is characterized by high commuting flows. The impact of this interaction is mix of urban and rural characteristics in East Ungaran District. This conditions will also affect land use in East Ungaran District, such as housing, economic facilities, and residential infrastructure. The increase of unplanned settlements has the potential to lead to inefficient land use, particularly in residential infrastructure. The purpose of this research is to examine patterns and characteristics of settlements in the East Ungaran District in 2015. This research uses descriptive quantitative with a spatial approach using remote sensing techniques. The results show that there are two types of settlement patterns in East Ungaran District, i.e, clustered pattern and random pattern. The characteristics of settlements are medium up to the good socio-economic condition (such as high income, good education, certificate ownership, permanent construction of housing, and good health) and good condition in infrastructure (determined by road conditions, sources of clean water, waste disposal systems, and sanitary systems).

Abstrak: Kecamatan Ungaran Timur merupakan wilayah peri urban yang terjadi akibat adanya interaksi desa-kota antara Kabupaten Semarang dengan Kota Semarang. Interaksi kedua wilayah ini didukung dengan adanya akses yang mudah yang ditandai dengan tingginya arus ulang-alik. Dampak dari interaksi wilayah yakni terjadinya percampuran karakteristik perkotaan dan pedesaan pada Kecamatan Ungaran Timur. Kondisi tersebut dapat mempengaruhi pemanfaatan lahan di Kecamatan Ungaran Timur, seperti pertambahan luas perumahan, peningkatan fasilitas ekonomi, dan prasarana permukiman lainnya. Pertambahan luas permukiman secara tidak terencana menyebabkan penggunaan lahan menjadi tidak efisien, khususnya dalam penyediaan prasarana permukiman. Penelitian ini bertujuan untuk mengkaji pola dan karakteristik permukiman di Kecamatan Ungaran Timur pada Tahun 2015. Metode penelitian yang digunakan adalah deskriptif kuantitatif dengan pendekatan spasial menggunakan data penginderaan jauh. Hasil penelitian menunjukkan bahwa terdapat dua jenis pola permukiman di Kecamatan Ungaran Timur, yaitu pola mengelompok dan pola acak/random. Karakteristik permukiman di Kecamatan Ungaran Timur memiliki kriteria kondisi sosial ekonomi yang baik (pendapatan rumah tangga yang cukup tinggi, tingkat pendidikan yang tinggi, adanya kepemilikan sertifikat hunian, konstruksi bangunan permanen, serta kondisi kesehatan yang baik) dan kondisi sarana prasarana yang baik (kondisi jalan, sumber air bersih, dan sistem persampahan yang baik, serta sistem sanitasi yang telah tersedia di kawasan permukiman).

Copyright (C) 2015 GJGP-UNDIP This open access article is distributed under a Creative Commons Attribution (CC-BY-NC-SA) 4.0 International license.

How to cite (APA 6th Style):

Arta, F. S, \& Pigawati, B. (2015). The patterns and characteristics of peri-urban settlement in East Ungaran District, Semarang Regency. Geoplanning: Journal Of Geomatics And Planning, 2(2), 103-115. doi:10.14710/geoplanning.2.2.103-115

\section{INTRODUCTION}

Villages and towns are areas on the surface of the earth that have different characteristics in terms of physical, human, and culture so that the potential between the two regions are different. Regional 
interaction between these areas occurs because there is no area that can fulfill the needs of their own regions. The main factor underlying this interaction is the existence of complementary regions, the opportunity to intervene each other, and ease of movement (Ulman, 1980). Rural-urban interactions lead to the emergence of peri urban area of a region with the mixture of urban and rural characteristics (Hudalah and Firman, 2012).

Semarang Regency and Semarang City are the two regions that have the opportunity to intervene each other because of their geographical position adjacent. This is illustrated in East Ungaran District (see Figure 1). Good accessibility conditions and the supply of high land drive the development of urban activities in this district. The existence of Semarang-Solo toll road Section I (Semarang-Ungaran) lead East Ungaran into one of the strategic areas in this region (Semarang Regency Regulation No. 6 year 2011- Semarang Regency Spatial Planning 2011-2031). This phenomenon causes the transformation of land use particularly from agricultural activities into built-up area such as housing, economic and infrastructure facilities of settlements. However, most of this transformation is unplanned that will lead to inefficiency of land use, particularly in the provision of settlement infrastructure.

Figure 1. Map of East Ungaran District (Development Planning Agency of Semarang Regency, 2011)

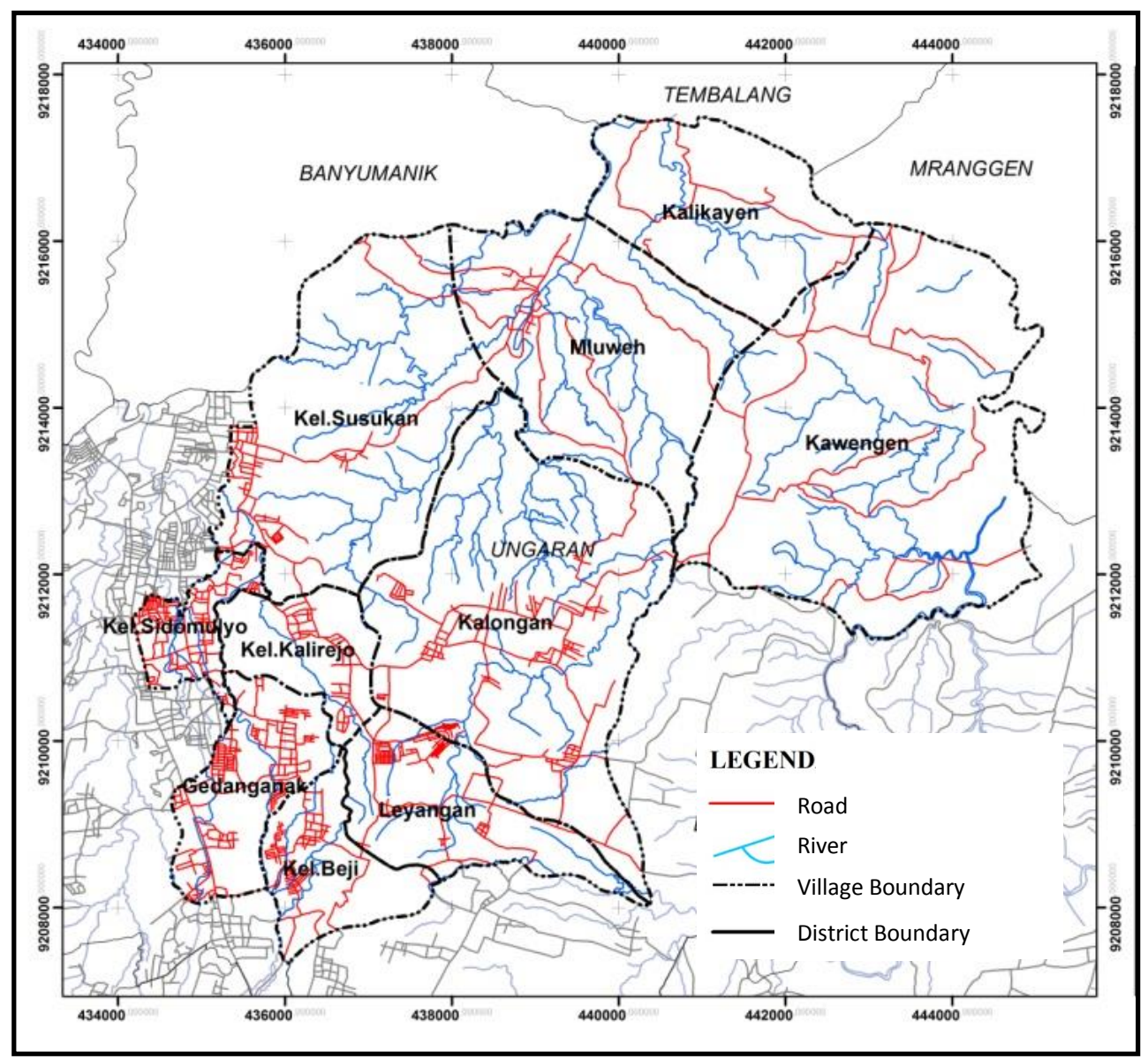

Based on these problems, research is conducted with the aim to assess the pattern and characteristics of settlements in peri-urban region of East Ungaran District. In order to achieve this aim, five analyses are conducted as follow:

1) Analysis of changes in land-use particularly in terms of ssettlement and non-settlement in East Ungaran District from 2005 up to 2015.

2) Analysis of the socio-economic condition of the East Ungaran district in 2015

3) Analysis of infrastructure conditions in East Ungaran District 2015

4) Analysis of settlement patterns of the East Ungaran District

5) Analysis of characteristics and settlement patterns of the East Ungaran District 


\section{DATA AND METHODS}

This research applied quantitative descriptive with spatial approach using remote sensing techniques. The purpose of using remote sensing techniques is to complete one of the goals of this research is the analysis of changes in land use settlement and non-settlement in the District of East Ungaran 2005 to 2015. In this study images taken at two times during the period that the image of 2005 and 2015 with a scale of 1: 10,000 . Furthermore, image interpretation is done to obtain data from the land use change from 2005 to 2015. Then test the accuracy of the interpretation of the results are proving to field conditions. Level of data accuracy strongly influences the confidence of users of each type of remote sensing data (Purwadhi and Sutanto, 1994). The limits of accuracy, minimal results of test calculations accuracy is $85 \%$. Remote sensing is the acquisition of physical data of an object without touching or mentioning (Lintz and Simonett, 1976). Another definition explains that remote sensing is the science of obtaining information on the object by measuring it from a distance or in the other words, the research has no actual intersection with the object (Davis et al, 1978). Remote sensing makes the data collection particularly on spatial information can be obtained in a short time and an affordable cost.

The suburban region is a zone which there is a mixing between the structure of the urban land and land countrylike (Serlin and Umilia, 2013). The transformation landuse ini peri urban area demonstrate that urbanisation in poverty is the key factor underpinning and catalysing changes in land use, land transaction, increased rural-urban immigration and the overall transformation of landuse (Kombe, 2005). The existing condition shows that a peri urban area growth rapidly in developing countries, such growth result in physical transformation of the environment and changes to livelihood activities (Cobbinah et al., 2015). The identification of the settlement are resulted in the detection of regular and irregular settlements. According Bintarto (1977), the pattern of settlement in terms of time and space can be analyzed using remote sensing and GIS and categorized into: disperse, random, clustered as illustrated in Figure $\mathbf{2}$.

Figure 2. Deployment of Nearest Neighbour (Bintarto, 1997)

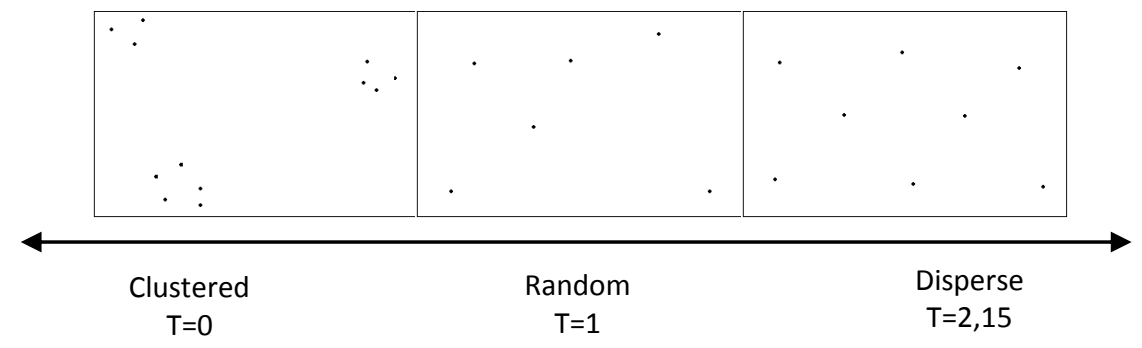

This approach is called the nearest neighbor analysis. This analysis requires data on the distance between the object with the closest neighbors. This approach is used to assess the geographical settlement. In analyzing the nearest neighbors, the researcher needs to conduct on the following steps (Figure 3);

1) Determining the delineation of the investigated areas

2) Change the object distribution pattern into a pattern distribution point.

3) Give the serial number for each point to facilitate analysis.

4) Measure the shortest distance of the distance in a straight line from one point to another point which is nearest neighbors and record this distance size.

5) Calculate the parameters of nearest neighbors or T with formula:

$T=\frac{j u}{j h}$

Where;

$T=$ Index spread nearest neighbor

ju= The average distance measured between the point with the nearest neighbor point

$\mathrm{Jh}=$ the average distance obtained suppose all points have random pattern 
Figure 3. Framework of research analysis (Author, 2015)

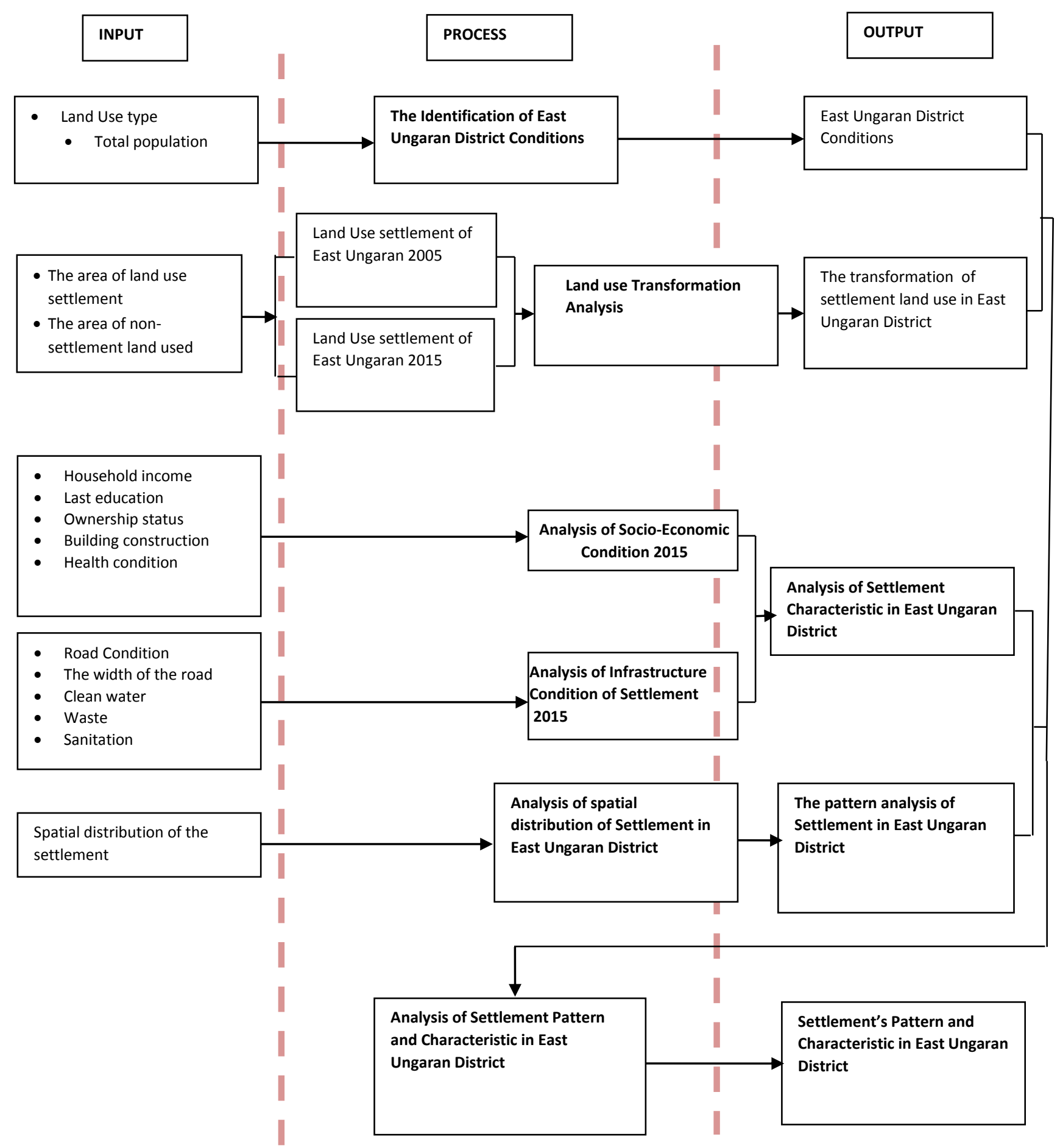

\section{RESULTS AND DISCUSSION}

\subsection{The analysis of Land use Transformation of Settlement and Non-Settlement Area}

The land use of East Ungaran district with an area of 6408.4 ha, consists of fresh water, building / industrial district, gardens, settlements, irrigated paddy-field, rainfed, and shrubs. In this study, a variety of land use was grouped into two types of land use, namely settlement and non-settlement. Table 1 below shows the transformation of settlement and non-settlement from 2005 to 2015. 
Table 1. Land use Transformation of Settlement and Non-Settlement Area 2005-2015

\begin{tabular}{|c|c|c|c|c|c|c|c|}
\hline \multirow[b]{2}{*}{ No } & \multirow{2}{*}{$\begin{array}{l}\text { Name of } \\
\text { Village }\end{array}$} & \multicolumn{2}{|l|}{2005} & \multicolumn{2}{|l|}{2015} & \multicolumn{2}{|c|}{$\begin{array}{l}\text { The growth of } \\
\text { settlement area }\end{array}$} \\
\hline & & $\begin{array}{l}\text { Settlement } \\
\text { (ha) }\end{array}$ & $\begin{array}{l}\text { Non } \\
\text { Settlement } \\
\text { (ha) }\end{array}$ & $\begin{array}{l}\text { Settlement } \\
\text { (ha) }\end{array}$ & $\begin{array}{l}\text { Non } \\
\text { Settlement } \\
\text { (ha) }\end{array}$ & (ha) & (\%) \\
\hline 1 & Beji & 41.4 & 208.4 & 72.05 & 177.75 & 30.64 & $8 \%$ \\
\hline 2 & Leyangan & 38.56 & 333.04 & 79.01 & 292.59 & 40.45 & $11 \%$ \\
\hline 3 & Kalongan & 56.35 & $1,172.75$ & 135.88 & $1,093.22$ & 79.53 & $21 \%$ \\
\hline 4 & Kawengen & 35.69 & $1,514.21$ & 88.7 & 1461.2 & 53.01 & $14 \%$ \\
\hline 5 & Kalikayen & 11.13 & 511.17 & 41.36 & 480.94 & 30.23 & $8 \%$ \\
\hline 6 & Mluweh & 18.28 & 776.72 & 40.32 & 754.68 & 22.03 & $6 \%$ \\
\hline 7 & Susukan & 52.33 & 891.57 & 89.81 & 854.09 & 37.47 & $10 \%$ \\
\hline 8 & Kalirejo & 30.64 & 196.06 & 53.72 & 172.98 & 23.07 & $6 \%$ \\
\hline 9 & Sidomulyo & 53.96 & 87.54 & 84.52 & 56.98 & 30.57 & $8 \%$ \\
\hline 10 & Gedanganak & 88 & 222.9 & 125.61 & 185.29 & 37.61 & $10 \%$ \\
\hline Total & & 426.34 & $5,914.36$ & 810.98 & $5,529.72$ & 384.61 & $100 \%$ \\
\hline
\end{tabular}

Based on Table 1 it can be seen, the greatest settlement increasement area in the village of Kalongan (79.53 ha) and added extensive smallest settlements occurred in the village of Mluweh (22.03 ha). Wide added East Ungaran district settlement can be viewed spatially in Figure 4.

Figure 4. Settlement Land use Growth Analysis (Analysis, 2015)

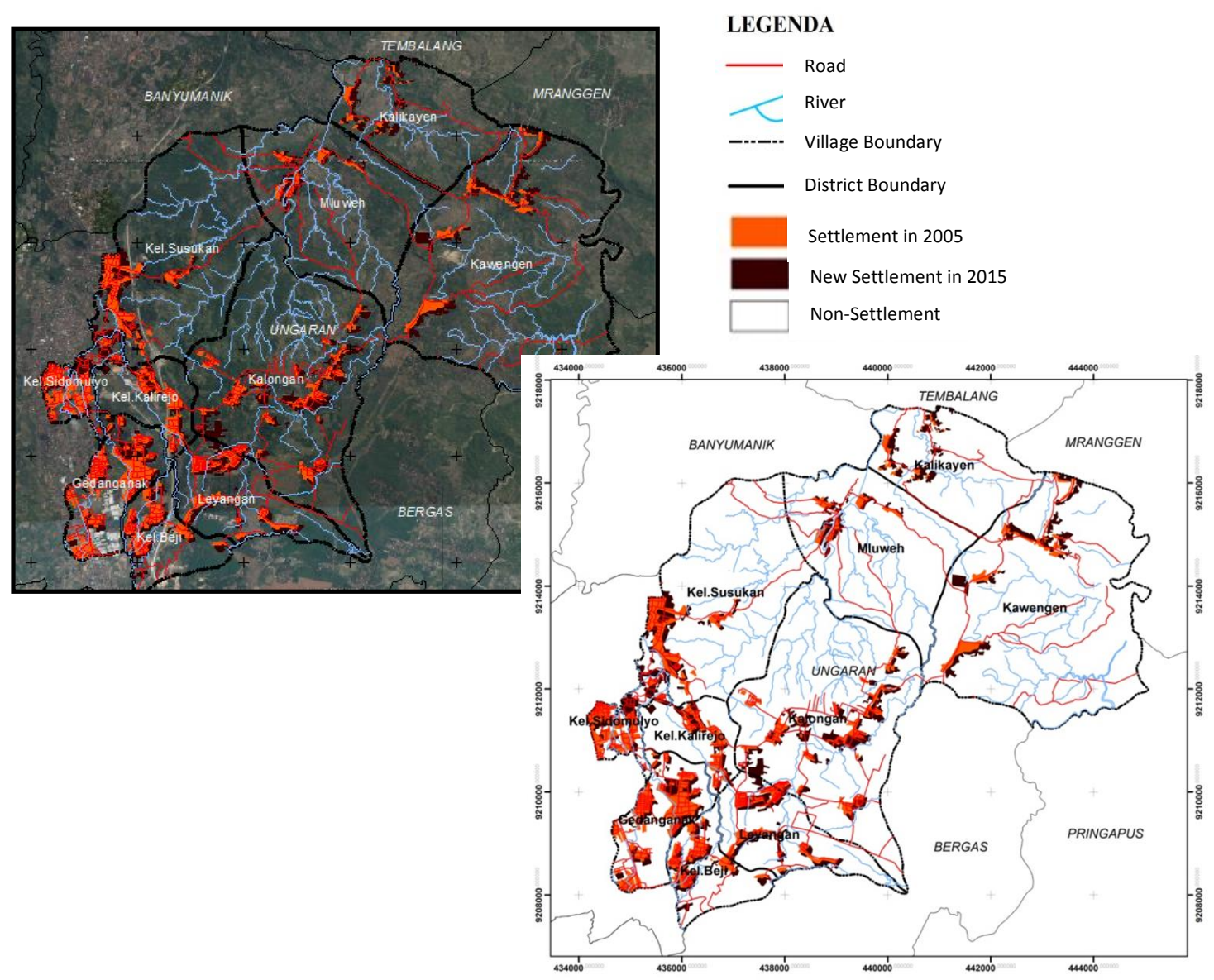




\subsection{Socio-economic Analysis of East Ungaran District}

Socio-economic conditions of society can be determined by analyzing several variables, including the amount of household income, education level, the status of ownership of land / houses, building construction, and health conditions.

1) Household Income

This study found that $22 \%$ of the people in the East Ungaran District have a total household income of more than Rp 3,000,000 per month, 32\% more people earn money from Rp 1,500,000 - Rp 3,000,000 per month, and the majority of people (46\%) only obtain less than Rp 1,500,000 per month.

2) Education Level

Most of East Ungaran district community $(47 \%)$ only have last education level until the junior high school and elementary school, $42 \%$ of communities have last education level up to secondary school (high school). Then a small portion (11\%) of East Ungaran district have last education level up to the level of bachelor's final.

3) The Ownership / status of land

This study found that 78\% East Ungaran District communities have a certificate on ownership, as much as $4 \%$ of people have house with land rights certificates, and the other $18 \%$ do not yet have a certificate.

4) Building (House) Construction

A total of $80 \%$ of the house is a permanent building , a small portion (7\%) of the population live in semipermanent buildings, and there are $13 \%$ of the population of East Ungaran still in non-permanent buildings. The illustration for each type of building construction can be seen in Figure 5 .

Figure 5. Building Construction of East Ungaran District (Analysis, 2015)

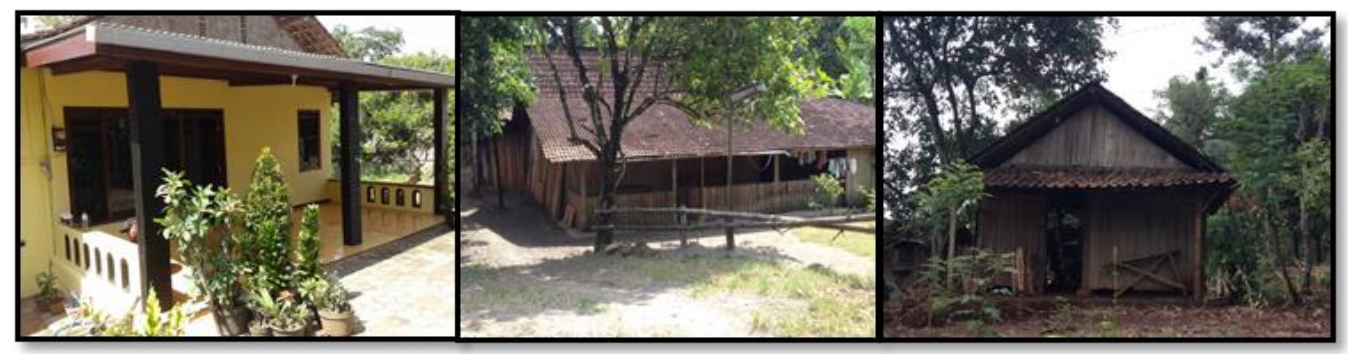

5) Health Condition

Based on the results of the study, $79 \%$ of the population in East Ungaran almost never sick, the other $20 \%$ of the population experience pain as much as 4-6 times a year, and the remaining $1 \%$ of the population was often in ill. Based on these results, it can be assumed that the sanitary conditions are quite good.

From all of these five variables, we can get the calculation on analysis of socio-economic conditions of East Ungaran district as shown in Table 2 below. The distribution of settlement based on social economic condition can be spatially mapped as shown on Figure 6 .

Table 2. The Analysis of Socio-economic condition of East Ungaran District (Analysis, 2015)

\begin{tabular}{|c|c|c|c|c|c|c|c|c|c|c|c|c|c|}
\hline \multirow{2}{*}{ No } & \multirow{2}{*}{ Village Name } & \multicolumn{2}{|c|}{ Income } & \multicolumn{2}{|c|}{$\begin{array}{l}\text { Level of } \\
\text { education }\end{array}$} & \multicolumn{2}{|c|}{ Land ownership } & \multicolumn{2}{|c|}{$\begin{array}{l}\text { Building } \\
\text { Construction }\end{array}$} & \multicolumn{2}{|c|}{$\begin{array}{l}\text { Healthy } \\
\text { Condition }\end{array}$} & \multicolumn{2}{|c|}{$\begin{array}{c}\text { Sosio-economic } \\
\text { Condition }\end{array}$} \\
\hline & & Score & Criteria & Score & Criteria & Score & Criteria & Score & Criteria & Score & Criteria & Score & Criteria \\
\hline 1 & Beji & 30 & Med & 30 & Med & 20 & Good & 20 & Good & 20 & Good & 120 & Good \\
\hline 2 & Leyangan & 30 & Med & 50 & Poor & 20 & Good & 20 & Good & 20 & Good & 140 & Good \\
\hline 3 & Kalongan & 50 & Poor & 50 & Poor & 20 & Good & 20 & Good & 20 & Good & 160 & Med \\
\hline 4 & Kawengen & 50 & Poor & 50 & Poor & 20 & Good & 20 & Good & 20 & Good & 160 & Med \\
\hline 5 & Kalikayen & 50 & Poor & 50 & Poor & 20 & Good & 50 & Poor & 20 & Good & 190 & Med \\
\hline
\end{tabular}




\begin{tabular}{|c|c|c|c|c|c|c|c|c|c|c|c|c|c|}
\hline \multirow{2}{*}{ No } & \multirow{2}{*}{ Village Name } & \multicolumn{2}{|c|}{ Income } & \multicolumn{2}{|c|}{$\begin{array}{l}\text { Level of } \\
\text { education }\end{array}$} & \multicolumn{2}{|c|}{ Land ownership } & \multicolumn{2}{|c|}{$\begin{array}{l}\text { Building } \\
\text { Construction }\end{array}$} & \multicolumn{2}{|c|}{$\begin{array}{l}\text { Healthy } \\
\text { Condition }\end{array}$} & \multicolumn{2}{|c|}{$\begin{array}{c}\text { Sosio-economic } \\
\text { Condition }\end{array}$} \\
\hline & & Score & Criteria & Score & Criteria & Score & Criteria & Score & Criteria & Score & Criteria & Score & Criteria \\
\hline 6 & Mluweh & 50 & Poor & 50 & Poor & 20 & Good & 50 & Poor & 20 & Good & 190 & Med \\
\hline 7 & Susukan & 30 & Med & 30 & Med & 20 & Good & 20 & Good & 20 & Good & 120 & Good \\
\hline 8 & Kalirejo & 20 & Good & 30 & Med & 20 & Good & 20 & Good & 20 & Good & 110 & Good \\
\hline 9 & Sidomulyo & 20 & Good & 30 & Med & 20 & Good & 20 & Good & 20 & Good & 110 & Good \\
\hline 10 & Gedanganak & 30 & Med & 30 & Med & 20 & Good & 20 & Good & 20 & Good & 120 & Good \\
\hline
\end{tabular}

Figure 6. Map of Settlement distribution based on Socio-Economic Condition (Analysis, 2015)

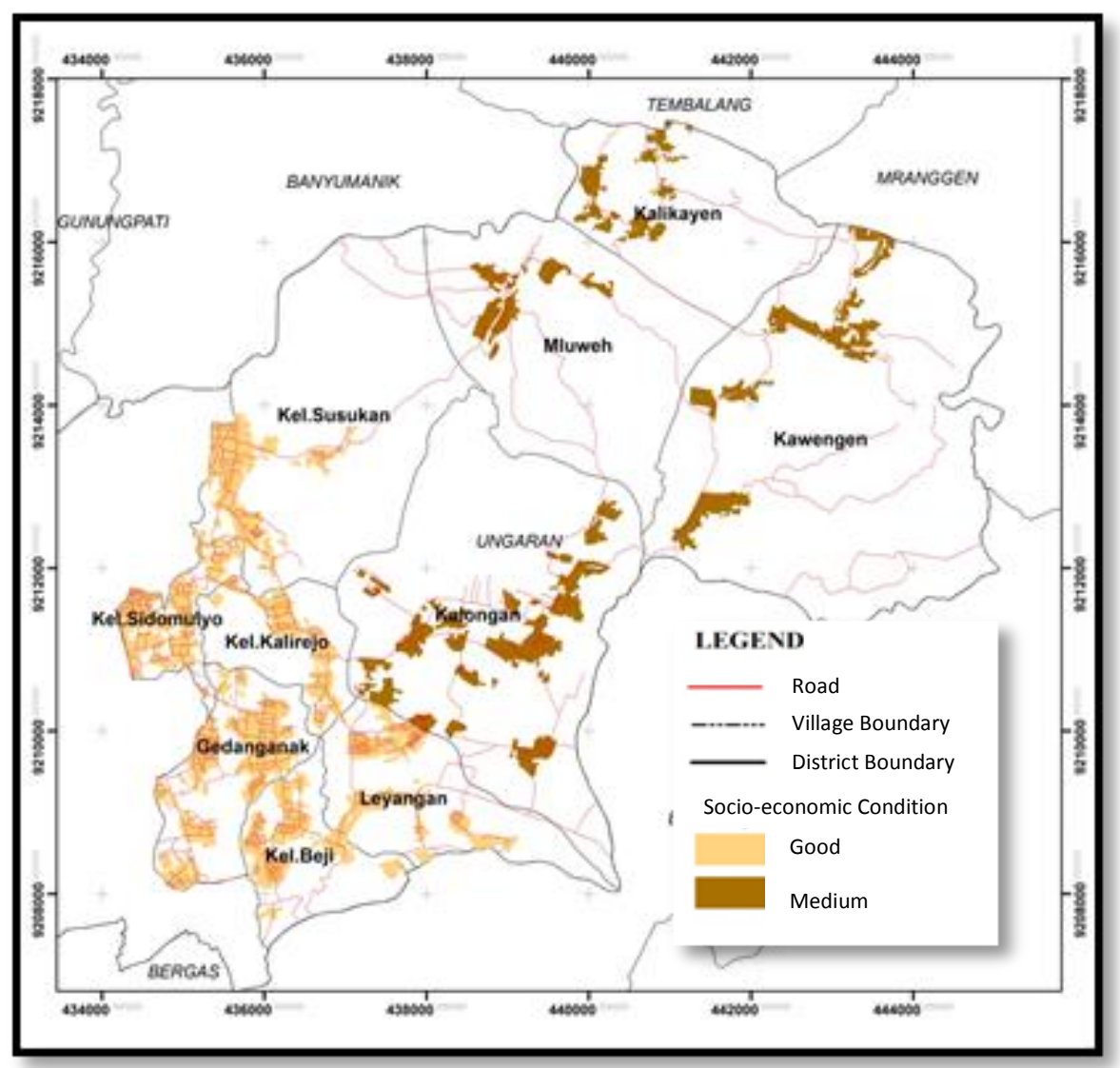

\subsection{Analysis of the Infrastructure in East Ungaran District}

Infrastructure conditions in a settlement area can be determined by analyzing some variables, such as the condition of roads, width of roads, water resources, waste management systems, and sanitation.

1) Road Condition

$61 \%$ of the neighborhoods in East Ungaran District have conditions of $>50 \%$ has been amplified using asphalt or concrete, the other $32 \%$ have paved roads covering $25-50 \%$ of the road, and a small proportion (7\%) neighborhood roads in East Ungaran District only hardened of $<25 \%$ of the roads, even some road still made of the soil. Based on the results of the analysis it is showed that most of the contained environment in settlement areas East Ungaran has been able to support a variety of activities or people with good movement. Local authorities are also able to build roads well.

2) Width of the road

As many as $17 \%$ of the neighborhoods in East Ungaran District has a road width of $>5 \mathrm{~m}$ so it can be passed by two cars. Then the majority (77\%) the neighborhoods have a road width of $2-5 \mathrm{~m}$ so it can only 
passed by one car and motorcycle. While $6 \%$ of other road have a road width $<2 \mathrm{~m}$ so it can only be passed by a motorcycle.

\section{3) Clean Water}

A total of $53 \%$ of the population using taps and artetics wells as a source of clean water, as many as $34 \%$ use wells as a source of clean water, and the other fraction of $13 \%$ of locals using the springs and rivers as a source of clean water.

4) Waste management System

Approximately $42 \%$ of neighborhoods in East Ungaran have a janitor who takes out the trash every week. Then $56 \%$ of other settlements are not covered by this system, so the waste is burned in the yard of the house. The remaining 3\% of population in East Ungaran District put their rubbish in the market and in the clearing.

\section{5) Sanitation System}

Generally speaking, the population in the district of East Ungaran (97\%) has its own sanitation system in each dwelling. Minority of the population (3\%), who do not have sanitation, uses river because there is no public sanitation facility in East Ungaran neighborhoods.

Condition of roads, roads width, and sanitation can be seen in Figure 7. The five variables, calculation analysis infrastructure conditions Ungaran district East is illustrated in Table 3. Furthermore, the distribution of settlements based infrastructure conditions can be spatially mapped in Figure 8 .

Figure 7. Road conditions, roads width, and sanitation (Analysis, 2015)

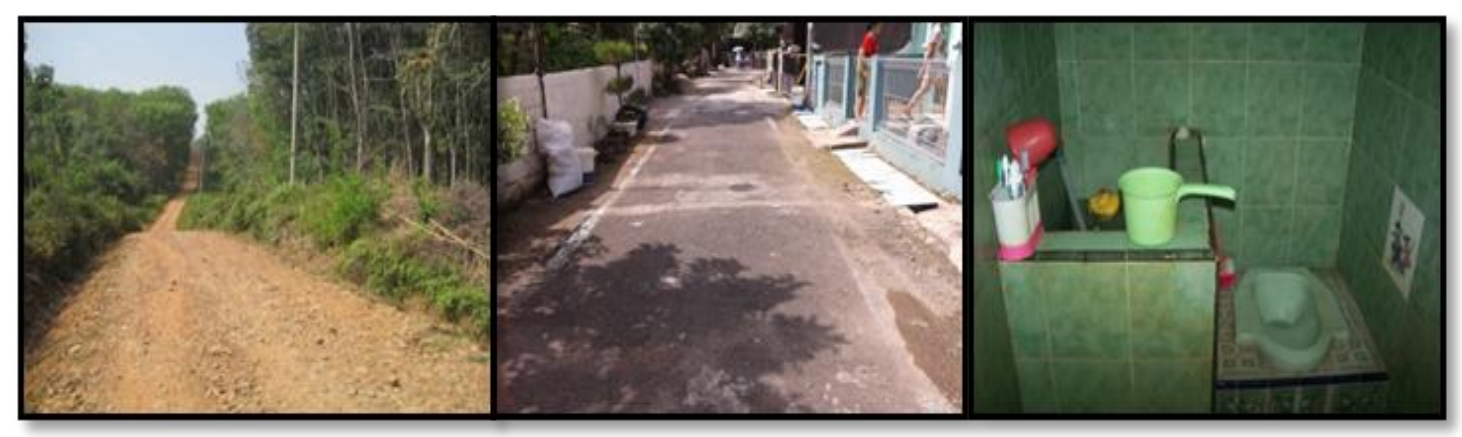

Table 3. Infrastructure Analysis of East Ungaran District

\begin{tabular}{|c|c|c|c|c|c|c|c|c|c|c|c|c|c|}
\hline \multirow[t]{2}{*}{ No } & \multirow{2}{*}{ Village Name } & \multicolumn{2}{|c|}{ Road condition } & \multicolumn{2}{|c|}{ Roads width } & \multicolumn{2}{|c|}{$\begin{array}{c}\text { Clean Water } \\
\text { Resources }\end{array}$} & \multicolumn{2}{|c|}{ Waste System } & \multicolumn{2}{|c|}{ Sanitation } & \multicolumn{2}{|c|}{$\begin{array}{l}\text { Infrastructure } \\
\text { assesment }\end{array}$} \\
\hline & & score & criteria & score & criteria & score & criteria & score & criteria & score & criteria & $\begin{array}{l}\text { Score } \\
\text { Total }\end{array}$ & Criteria \\
\hline 1 & Beji & 20 & Good & 30 & Med & 20 & Good & 20 & Good & 20 & Good & 110 & Good \\
\hline 2 & Leyangan & 20 & Good & 20 & Good & 20 & Good & 20 & Good & 20 & Good & 100 & Good \\
\hline 3 & Kalongan & 30 & Med & 30 & Med & 20 & Good & 30 & Med & 20 & Good & 130 & Good \\
\hline 4 & Kawengen & 30 & Med & 30 & Med & 50 & Poor & 30 & Med & 20 & Good & 160 & Med \\
\hline 5 & Kalikayen & 30 & Med & 30 & Med & 30 & Med & 30 & Med & 20 & Good & 140 & Good \\
\hline 6 & Mluweh & 30 & Med & 30 & Med & 30 & Med & 30 & Med & 20 & Good & 140 & Good \\
\hline 7 & Susukan & 20 & Good & 30 & Med & 20 & Good & 20 & Good & 20 & Good & 110 & Good \\
\hline 8 & Kalirejo & 20 & Good & 30 & Med & 20 & Good & 20 & Good & 20 & Good & 110 & Good \\
\hline 9 & Sidomulyo & 20 & Good & 30 & Med & 30 & Med & 20 & Good & 20 & Good & 120 & Good \\
\hline 10 & Gedanganak & 20 & Good & 30 & Med & 20 & Good & 20 & Good & 20 & Good & 110 & Good \\
\hline
\end{tabular}


Figure 8. Map of Settlement distribution based on Infrastructure Condition (Analysis, 2015)

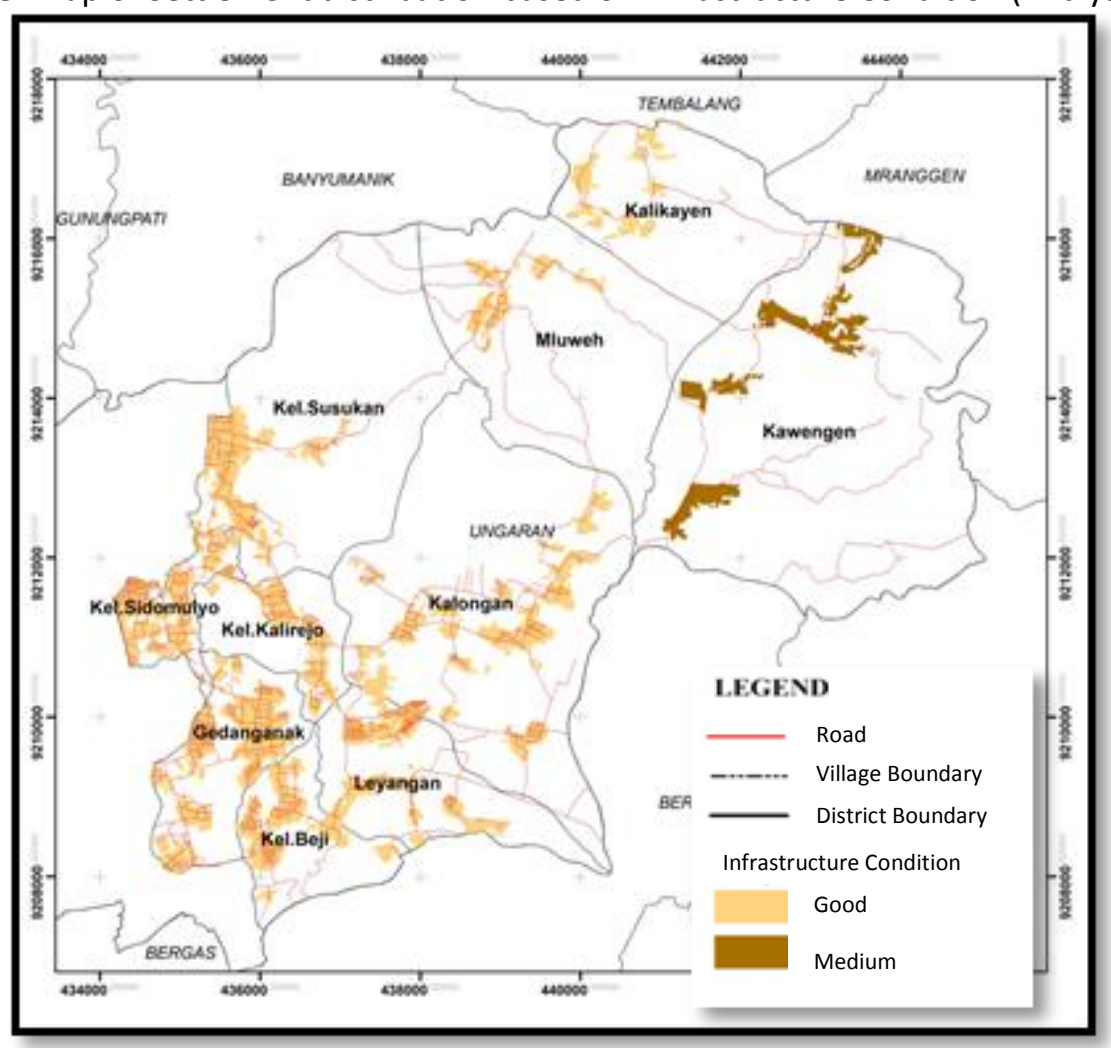

\subsection{Analysis of the Infrastructure in East Ungaran District}

Nearest neighbor analysis calculation is done by identifying spread point of settlements in East Ungaran DIstrict. Each point represents one area of existing settlements. The number of points that represent settlements in East Ungaran is 193 points divided into 10 Villages / Village. The distribution points that connect the settlements and the distance of each settlement can be seen in Figure 9 .

Figure 9. Map of Settlement Distribution and Interction in East Ungaran District (Analysis, 2015)

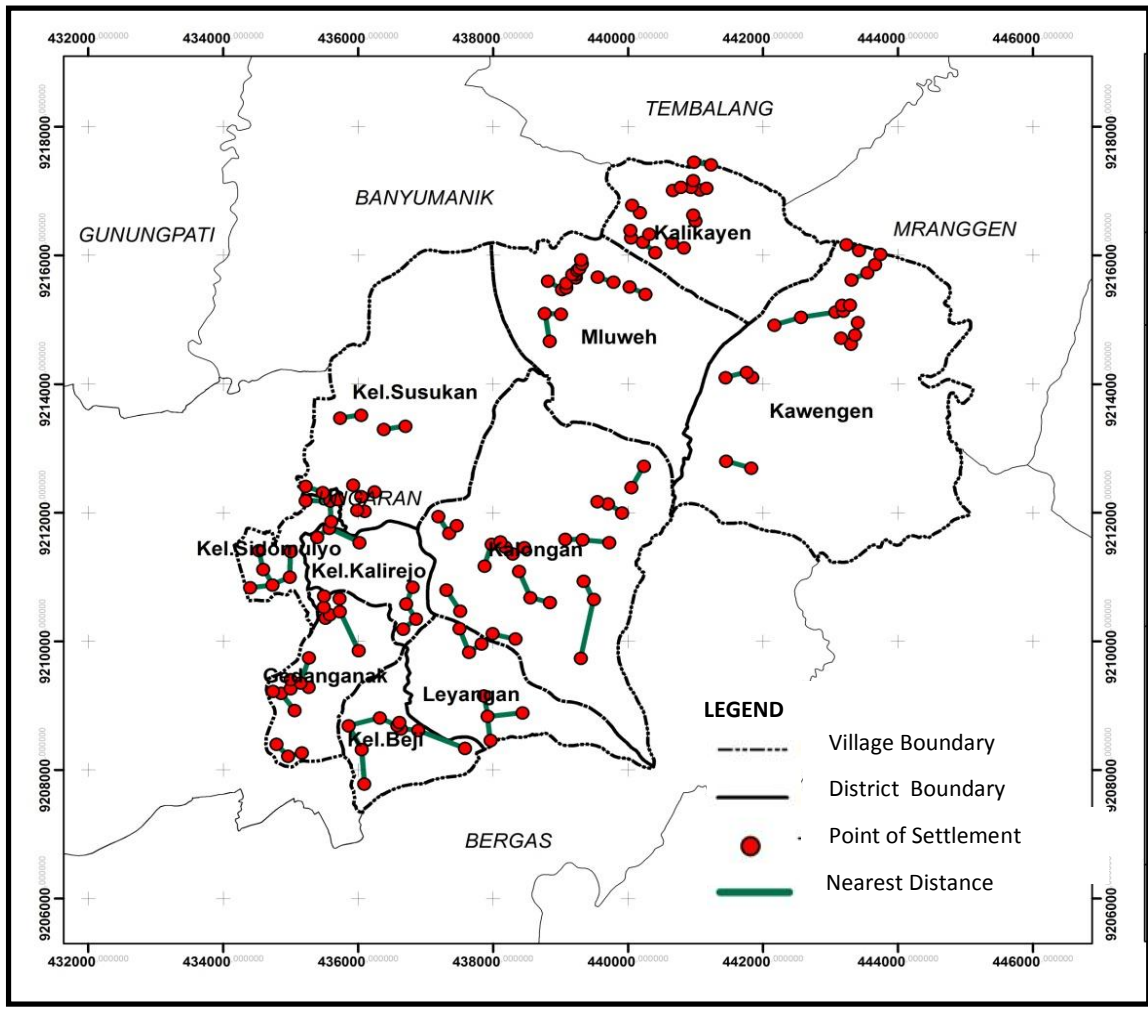


Here is an example of a matrix calculation of settlement patterns of the village/villages in the East Ungaran District. Further calculations for rural settlement patterns/other villages, was carried out in the same way.

a. Beji

$$
\begin{aligned}
T & =\frac{j u}{j h} \\
T & =\frac{0,13}{0,26} \\
T & =0,49 \text { (close to clustered pattern) }
\end{aligned}
$$

b. Leyangan

$$
\begin{aligned}
T & =\frac{j u}{j h} \\
T & =\frac{0,34}{0,36} \\
T & =0,93 \text { (close to random pattern) }
\end{aligned}
$$

\begin{tabular}{|c|c|c|c|c|c|c|c|}
\hline No & Village name & $\begin{array}{l}\text { Settlement } \\
\text { Pattern }\end{array}$ & $\begin{array}{c}\text { Socio } \\
\text { Economic } \\
\text { Score }\end{array}$ & $\begin{array}{l}\text { Infrastructure } \\
\text { Score }\end{array}$ & $\begin{array}{l}\text { Score } \\
\text { Total }\end{array}$ & Criteria & Characteristics \\
\hline 1 & Beji & $\begin{array}{l}T=0,49 \\
\text { (close to } \\
\text { clustered) }\end{array}$ & 120 & 110 & 230 & Good & $\begin{array}{l}\text { - Socio-economic conditions are good; total } \\
\text { household income is Rp 1,500,000 and Rp } \\
3,000,000 \text {, level of past education is high } \\
\text { school, ownership certificate of the land, } \\
\text { the houses are permanent buildings, and } \\
\text { people in good health. } \\
\text { - Good condition of infrastructure; the } \\
\text { hardened road in the settlement is more } \\
\text { than } 50 \% \text { and has a width of } 2-5 \mathrm{~m} \text {, water } \\
\text { source comes from PAM and artesian wells, } \\
\text { scheduled waste collecting systems, and } \\
\text { sanitation. }\end{array}$ \\
\hline 2 & Leyangan & $\begin{array}{l}T=0,93 \\
\text { (close to } \\
\text { random) }\end{array}$ & 140 & 100 & 240 & Good & $\begin{array}{l}\text { - Socio-economic conditions well; total } \\
\text { household income of Rp 1,500,000 and Rp } \\
3,000,000 \text {, education level elementary and } \\
\text { junior high school, ownership certificate, } \\
\text { construction of permanent buildings, and in } \\
\text { good health. } \\
\text { - Condition good infrastructure; settlements } \\
\text { already hardened road conditions more } \\
\text { than } 50 \% \text { and has a width of more than } 5 \mathrm{~m} \text {, } \\
\text { the source of water comes from PAM and } \\
\text { artesian wells, scheduled waste } \\
\text { transportation systems, and sanitation. }\end{array}$ \\
\hline 3 & Kalongan & $\begin{array}{l}T=0,89 \\
\text { (close to } \\
\text { random) }\end{array}$ & 160 & 130 & 290 & Good & $\begin{array}{l}\text { - Socio-economic conditions medium; total } \\
\text { household income of less than Rp } \\
1,500,000 \text {, education level elementary and } \\
\text { junior high school, ownership certificate, } \\
\text { construction of permanent buildings, and in } \\
\text { good health } \\
\text { - Condition good infrastructure; settlements }\end{array}$ \\
\hline
\end{tabular}

\subsection{Analysis of the Infrastructure in East Ungaran District}

Based on the previous analyses, the patterns and characteristics of settlements in East Ungaran District can be seen in Table 4.

Table 4. The Pattern and the Characteristic of Settlement in East Ungaran District (Analysis, 2015) 


\begin{tabular}{|c|c|c|c|c|c|c|}
\hline No & Village name & $\begin{array}{l}\text { Settlement } \\
\text { Pattern }\end{array}$ & $\begin{array}{c}\text { Socio } \\
\text { Economic } \\
\text { Score }\end{array}$ & $\begin{array}{c}\text { Infrastructure } \\
\text { Score }\end{array}$ & $\begin{array}{l}\text { Score } \\
\text { Total }\end{array}$ & Criteria \\
\hline 4 & Kawengen & $\begin{array}{l}T=0,51 \\
\text { (close to } \\
\text { random) }\end{array}$ & 160 & 160 & 320 & Med \\
\hline 5 & Kalikayen & $\begin{array}{l}T=0,58 \\
\text { (close to } \\
\text { random) }\end{array}$ & 190 & 140 & 330 & Med \\
\hline 6 & Mluweh & $\begin{array}{l}T=0,46 \\
\text { (close to } \\
\text { clustered) }\end{array}$ & 190 & 140 & 330 & Med \\
\hline
\end{tabular}

already hardened road conditions $25 \%$ $50 \%$ and has a width of $2-5 \mathrm{~m}$ roads, water source comes from PAM and artesian wells, manage waste by burning, and sanitation.

- Socio-economic conditions medium; total household income of less than $\mathrm{Rp}$ $1,500,000$, education level to elementary and junior high school, ownership certificate, construction of permanent buildings, and in good health.

- The condition of infrastructure being; settlements already hardened road conditions $25 \%-50 \%$ and has a road width 2-5m, source water comes from springs and streams, managing waste by burning, and sanitation.

Socio-economic conditions medium; total household income of less than Rp $1,500,000$, education level elementary and junior high school, ownership certificate, building construction non-permanent, and in good health.

- Condition good infrastructure; settlements already hardened road conditions $25 \%$ $50 \%$ and has a width of $2-5 \mathrm{~m}$ roads, water supply comes from wells, manage waste by burning, and sanitation.

- Socio-economic conditions were; total household income of less than $\mathrm{Rp}$ $1,500,000$, education level to elementary and junior high school, ownership certificate, building construction nonpermanent, and in good health.

- Condition good infrastructure; settlements already hardened road conditions $25 \%$ $50 \%$ and has a width of $2-5 \mathrm{~m}$ roads, water supply comes from wells, manage waste by burning, and sanitation.

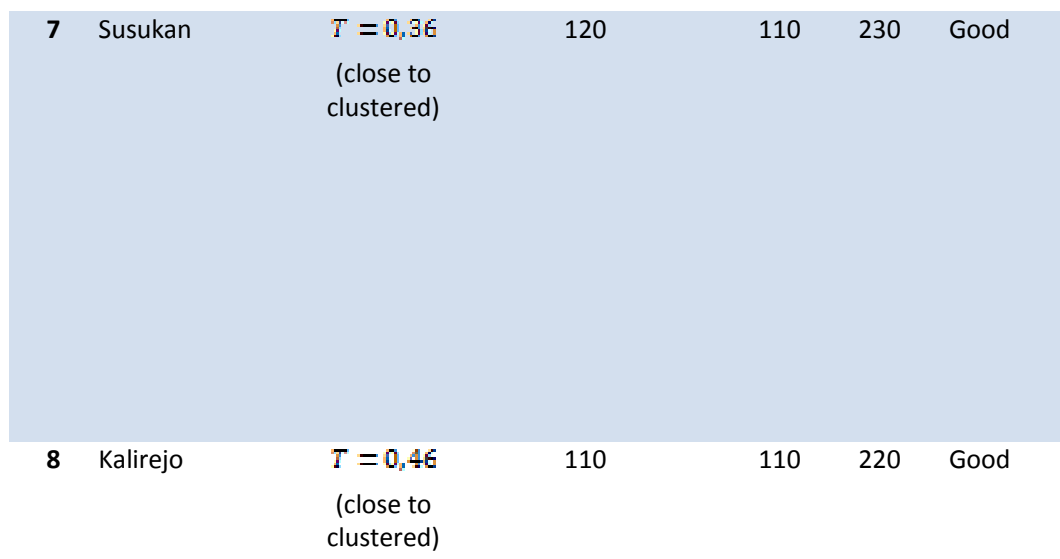

Socio-economic conditions well; total

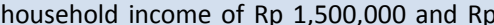
$3,000,000$, education level up to the high school level, certificate of ownership, the construction of permanent buildings, and in good health.

- Condition good infrastructure; settlements already hardened road conditions more than $50 \%$ and has a width of $2-5 \mathrm{~m}$ roads, water source comes from PAM and artesian wells, waste transportation system are scheduled, and sanitation.

- Socio-economic conditions well; total household income of more than USD $3,000,000$, level of education past high school, ownership certificate, construction of permanent buildings, and in good health.

- Condition good infrastructure; settlements already hardened road conditions more than $50 \%$ and has a width of $2-5 \mathrm{~m}$ roads, water source comes from PAM and artesian wells, scheduled waste transportation systems, and sanitation.

\begin{tabular}{|c|c|c|c|c|c|c|}
\hline 9 Sidomulyo & $\begin{array}{c}0,49 \\
\text { (close to } \\
\text { clustered) }\end{array}$ & 110 & 120 & 230 & Good & $\begin{array}{l}\text { - Socio-economic conditions well; total } \\
\text { household income of more than USD } \\
3,000,000 \text {, level of education past high } \\
\text { school, ownership certificate, construction } \\
\text { of permanent buildings, and in good }\end{array}$ \\
\hline
\end{tabular}




\begin{tabular}{|c|c|c|c|c|c|c|c|}
\hline No & Village name & $\begin{array}{c}\text { Settlement } \\
\text { Pattern }\end{array}$ & $\begin{array}{c}\text { Socio } \\
\text { Economic } \\
\text { Score }\end{array}$ & $\begin{array}{l}\text { Infrastructure } \\
\text { Score }\end{array}$ & $\begin{array}{l}\text { Score } \\
\text { Total }\end{array}$ & Criteria & Characteristics \\
\hline & & & & & & & $\begin{array}{l}\text { health. } \\
\text { - Condition good infrastructure; settlements } \\
\text { already hardened road conditions more } \\
\text { than } 50 \% \text { and has a width of } 2-5 \mathrm{~m} \text { roads, } \\
\text { water supply comes from wells, waste } \\
\text { transportation system has scheduled, and } \\
\text { sanitation. }\end{array}$ \\
\hline 10 & Gedanganak & $\begin{array}{l}T=0,92 \\
\text { (close to } \\
\text { random) }\end{array}$ & 120 & 110 & 230 & Good & $\begin{array}{l}\text { - Socio-economic conditions well; total } \\
\text { household income of Rp } 1,500,000 \text { and Rp } \\
3,000,000 \text {, education level up to the high } \\
\text { school level, certificate of ownership, the } \\
\text { construction of permanent buildings, and } \\
\text { in good health. } \\
\text { - Condition good infrastructure; settlements } \\
\text { already hardened road conditions more } \\
\text { than } 50 \% \text { and has a width of } 2-5 \mathrm{~m} \text { roads, } \\
\text { water supply comes from wells, waste } \\
\text { transportation system has scheduled, and } \\
\text { sanitation. }\end{array}$ \\
\hline
\end{tabular}

\section{CONCLUSION}

In total, the transformation of non settlement in settlement area in the the East Ungaran District in 2005-2015 is about $384.63 \mathrm{Ha}$. The largest transformation is occurred in the Kalongan (79.53 Ha). This phenomenon may be influenced by large enough supply of land, tend to be flat topography, and the location adjacent of Kalongan to the Kalirejo (the area passed Semarang-Solo toll booth). While the smallest transformation occurred in the Mluweh $(22.03 \mathrm{Ha})$ that may be influenced by the location of the village that is far from the center of activities.

There are two types of settlement patterns in the East Ungaran District, i.e. approaching clustered pattern and random approach. Clustered settlement pattern is illustrated in the Beji, Mluweh, Susukan, Kalirejo, as well as in Sidomulyo. While the random pattern of settlements is illustrated in the Leyangan, Kalongan, Kawengen, Kalikayen, and Gedanganak.

Based on the socio-economic conditions, the settlement in the Beji, Leyangan, Susukan, Kalirejo, Sidomulyo, and Gedanganak are grouped into good socio-economic conditions. While the Kalongan, Kawengen, Kalikayen, and Mluweh in the criteria for being classified. Furthermore based on the condition of facilities and infrastructure, all settlements in the all villages have good facilities and infrastructures.

\section{REFERENCES}

Adam, A. G. (2014). Informal settlement in peri-urban areas of Bahir Dar, Ethiopia: An institutional Analysis. Habitat International, 43, 90-97

Bappeda Kabupaten Semarang. (2011). Peraturan Daerah Kabupaten Semarang Nomor 6 Tahun 2011 tentang RTRW Kabupaten Semarang Tahun 2011-2031.

Bintarto, R. (1979). Metode Analisa Geografi. Jakarta: LP3ES.

Cobbinah, et al. (2015). Peri-urban morphology and indigenous livelihoods in Ghana. Habitat International, 50, $120-129$.

Daldjoeni. (1996). Geografi kota dan desa. Bandung: P.T. Alumni.

Davis, S. M., et. al. (1978). Remote sensing: the quantitative approach. New York, McGraw-Hill International Book Co., 1978. 405 p., 1.

Hudalah, D., \& Firman, T. (2012). Industrial estates and post-suburban transformation in Jakarta Metropolitan Region. Cities, 29, 40-48.

Indarto. (2014). Teori dan praktek penginderaan jauh. Yogyakarta: ANDI.

Kombe, W. J. (2005). Land use dynamic In peri-urban areas and their implications on the urban growth and form: the case of Dar Es Salaam, Tanzania. Habitat International, 29 (1), 113-135. 
Lintz, J., \& Simonett, D. S. (1976). Remote sensing of environment. Addison-Weslcy. Reading, Mass.

Purwadhi, S., \& Sanjoto, T. (2008). Pengantar interpretasi citra penginderaan jauh. Lembaga Penerbangan dan Antariksa Nasional - Universitas Negeri Semarang.

Purwadhi, F., \& Sutanto, R. (1994). Dayaguna spot dan landsat untuk pemetaan penggunaan lahan pertanian di Bekasi dan sekitarnya dengan skala 1: 100.000 (Doctoral dissertation, Universitas Gadjah Mada).

Ulman, Edward. (1980). Geography as Spatial Interaction. Washington: University of Washington Press.

Umilia, E., \& Serlin, M. A. (2013). Faktor-faktor yang mempengaruhi masyarakat dalam memilih lokasi hunian peri urban Surbaya di Sidoarjo. Jurnal Teknik Pomits, 2(2): 143-148.

Yunus, H. S. (2008). Dinamika wilayah peri-urban: determinan masa depan kota. Yogyakarta: Pustaka Pelajar. 